\title{
GAMBARAN PENGETAHUAN WANITA PADA PASANGAN USIA SUBUR TENTANG PENYAKIT SIFILIS DI WILAYAH KERJA PUSKESMAS BATU AJI KOTA BATAM
}

\author{
Rosi Esa Gustina1, Bintang Sekar Ayu Br. Manurung ${ }^{2}$ \\ ${ }^{1}$ Dosen Akademi Kebidanan Putra Jaya Mandiri Batam, \\ ${ }^{2}$ Mahasiswa Diploma III Akademi Kebidanan Putra Jaya Mandiri Batam, \\ Jl. Prambanan No.99 Sei Jodoh-Kota Batam \\ Email: rosi_esa_gustina@yahoo.com
}

\begin{abstract}
ABSTRAK
Sifilis adalah penyakit menular seksual infeksius, yang disebabkan Treponema pallidum. Jumlah kasus sifilis setiap tahun terus meningkat, khususnya di Kota Batam, angka kejadian sifilis dalam 3 tahun terakhir semakin bertambah dengan penderita terbanyak adalah wanita pada usia 20-45 tahun. Penelitian ini bertujuan mengetahui gambaran pengetahuan wanita pada pasangan usia subur tentang penyakit sifilis di wilayah kerja Puskesmas Batu Aji Kota Batam tahun 2018.

Penelitian ini bersifat deskriptif kuantitatif dengan alat pengumpulan data menggunakan angket, yang berisi 20 pertanyaan terhadap 40 responden, yaitu wanita pada pasangan usia subur di wilayah kerja Puskesmas Batu Aji Kota Batam yang dilakukan pada bulan September-November 2018.

Dari hasil rata-rata tingkat pengetahuan wanita pada pasangan usia subur tentang penyakit sifilis menunjukkan dari 40 responden, sejumlah 19 responden $(47,5 \%)$ memiliki pengetahuan cukup, 7 responden (17,5\%) memiliki pengetahuan baik dan 14 responden (35\%) memiliki pengetahuan kurang. Berdasarkan hasil penelitian dapat disimpulkan tingkat pengetahuan wanita pada pasangan usia subur tentang penyakit sifilis di Puskesmas Batu Aji Kota Batam Tahun 2018, memiliki pengetahuan cukup tentang penyakit sifilis.
\end{abstract}

Kata Kunci: Sifilis, Wanita, Pasangan Usia Subur

\section{PENDAHULUAN}

Sifilis merupakan penyakit infeksi menular seksual yang disebabkan oleh Treponema palidum. Penyakit sifilis dapat mengenai seluruh organ tubuh, mulai dari kulit, mukosa, jantung hingga susunan syaraf pusat dan juga dapat tanpa manifestasi lesi di tubuh (Sarwono, 2009).

Penyakit sifilis dapat ditularkan melalui selaput lendir (vagina, mulut dan melalui kulit), penularan penyakit ini dapat terjadi melalui hubungan kelamin, oral sex dan juga dapat terjadi dari ibu pada janin selama masa kehamilan. Sifilis merupakan penyakit kelamin yang berbahaya dimana jika tidak segera diobati maka berisiko mengalami penyakit yang cukup berbahaya yaitu HIV/AIDS. Perlu diketahui bahwa luka ataupun sakit yang diderita tidak hanya dirasakan disekitar kelamin saja akan tetapi juga meliputi di beberapa bagian tubuh (Djuanda $A, 2010$ ). Pada pasangan usia subur, penyakit sifilis tidak hanya membahayakan dirinya sendiri, namun juga membahayakan pasangannya. 
Berdasarkan data WHO (2012) diperkirakan terdapat 5,6 juta kasus baru sifilis diseluruh dunia pada tahun 2012, yang terjadi dikalangan remaja dan orang dewasa berusia 15-49 tahun. Diperkirakan 18 juta kasus umum sifilis pada tahun 2012 dengan prevalensi global $0,5 \%$ di antara wanita dan 0,5\% di antara pria (Pan American Health Organization, 2018).

Di Indonesia terjadi peningkatan kejadian sifilis di beberapa provinsi antara lain Profil Kesehatan Provinsi Jawa Tengah Tahun 2015, jumlah kasus sifilis di Jawa Tengah tahun 2015 sebanyak 1.206 kasus, meningkat dibandingkan tahun 2014 sebanyak 907 kasus. Di Kota Padang pada tahun 2013 terjadi peningkatan jumlah kasus sifilis sejumlah 22 kasus (Dinkes Padang, 2014). Pada tahun 2013 terjadi peningkatan jumlah kasus sifilis di Provinsi Lampung jumlah kasus infeksi menular seksual termasuk sifilis tahun 2012 sebesar 3.153 kasus dengan penderita wanita sebanyak 2.942 kasus dan pria sebesar 419 kasus, merupakan jumlah kasus terbanyak dibanding kota-kota lain (Profil Kesehatan Provinsi Lampung, 2013).

Menurut Dinas Kesehatan Kota Batam jumlah penderita sifilis terbanyak adalah pada usia 25-49 tahun dimana pada tahun 2015 sebanyak 59 kasus penyakit sifilis dengan jumlah lebih banyak perempuan 37 orang dan laki-laki 22 orang. Pada tahun 2016 penderita sifilis di Kota Batam adalah sebanyak 75 kasus. Jumlah penderita perempuan jauh lebih banyak dibandingkan laki-laki dimana 48 kasus pada perempuan dan 27 kasus pada laki-laki. Kemudian pada tahun 2017 kasus sifilis yang terjadi di Kota Batam meningkat sebanyak 94 kasus penyakit sifilis dengan jumlah sedikit lebih banyak laki-laki dengan 49 orang dan perempuan sebanyak 45 orang.

Kasus sifilis banyak terjadi pada wanita pada pasangan usia subur dikarenakan rendahnya pengetahuan wanita terhadap bahaya yang ditimbulkan oleh penyakit sifilis. Sehingga banyak penularan yang sering terjadi karena minimnya rasa ingin tahu, padahal dari pihak rumah sakit atau puskesmas sering memberi penyuluhan mengenai gejala dan bahaya yang ditimbulkan penyakit ini.

Penelitian ini bertujuan untuk mengetahui gambaran pengetahuan wanita pada pasangan usia subur tentang penyakit sifilis di wilayah kerja Puskesmas Batu Aji Kota Batam tahun 2018.

\section{METODE}

Penelitian ini merupakan penelitian deskriptif kuantitatif yang dilaksanakan di wilayah kerja Puskesmas Batu Aji Kota Batam pada bulan September-November tahun 2018.

Populasi dalam penelitian ini adalah seluruh pasangan usia subur yang ada di wilayah kerja Puskesmas Batu Aji Kota Batam tahun 2018 yang berjumlah 26,738 orang. Sampel dalam penelitian ini adalah wanita pada pasangan usia subur di wilayah kerja Puskesmas Batu Aji Kota Batam yang 
berjumlah 40 orang. Pengambilan sampling menggunakan teknik accidental sampling dengan alat pengumpulan data menggunakan angket (Saryono,2012 dan Notoadmodjo,2013).

Data yang diperlukan dalam penelitian ini dikumpulkan dengan menggunakan data primer yang diperoleh langsung dari wanita pada pasangan usia subur yang ada di wilayah kerja Puskesmas Batu Aji Kota Batam. Analisa data dilakukan untuk melihat hasil perhitungan frekuensi, presentase yang ingin diteliti meliputi gambaran pengetahuan pasangan usia subur terhadap penyakit sifilis di wilayah kerja puskesmas Batu Aji Kota Batam tahun 2018 dengan menggunakan rumus sebagai berikut:

$$
\mathrm{P}=\frac{\mathrm{f}}{\mathrm{n}} \times 100 \%
$$

Keterangan:

$\mathrm{P}=$ presentasi yang dicari

$\mathrm{f}$ = banyaknya jawaban (jumlah skor seluruh responden)

$\mathrm{N}$ = jumlah sampel

(Machfoedz,2010).

\section{HASIL}

Berdasarkan hasil penelitian yang dilakukan mengenai gambaran pengetahuan wanita pada pasangan usia subur terhadap penyakit sifilis di wilayah kerja Puskesmas Batu Aji Kota Batam tahun 2018 terhadap 40 orang wanita pada pasangan usia subur di Puskesmas Batu Aji di dapatkan hasil sebagai berikut:

\section{Pengetahuan tentang Pengertian Penyakit Sifilis}

Tabel 1. Distribusi Frekuensi Tingkat Pengetahuan Wanita pada Pasangan Usia Subur tentang Pengertian Penyakit Sifilis di Wilayah Kerja Puskesmas Batu Aji Kota Batam tahun 2018.

\begin{tabular}{|c|c|c|c|}
\hline No & Kategori & $\begin{array}{c}\text { Frekuensi } \\
\text { (f) }\end{array}$ & $\begin{array}{c}\text { Persentase } \\
(\%)\end{array}$ \\
\hline 1 & Baik & 17 & 42.5 \\
\hline 2 & Cukup & 10 & 25 \\
\hline \multirow[t]{2}{*}{3} & Kurang & 13 & 32,5 \\
\hline & Jumlah & 40 & 100 \\
\hline Sum & r: $\begin{array}{l}\text { Hasil } \\
\text { Sept }\end{array}$ & $\begin{array}{l}\text { penelitian } \\
\text { nber } 2018 .\end{array}$ & Bulan \\
\hline
\end{tabular}

Tabel 1 diatas menujukkan hasil analisa penelitian pengetahuan wanita pada pasangan usia subur tentang pengertian penyakit sifilis di wilayah kerja Puskesmas Batu Aji Kota Batam tahun 2018, dari 40 responden sebanyak 17 responden $(42,5 \%)$, mayoritas atau sebagian besar memiliki pengetahuan baik, 10 responden (25\%) memiliki pengetahun cukup, 13 responden (32,5\%) memiliki pengetahuan kurang.

\section{Pengetahuan tentang Cara Penularan} Penyakit Sifilis

Tabel 2. Distribusi Frekuensi Tingkat Pengetahuan Wanita pada Pasangan Usia Subur tentang Cara Penularan Penyakit Sifilis di Wilayah Kerja Puskesmas Batu Aji Kota Batam tahun 2018

\begin{tabular}{cccc}
\hline No & Kategori & $\begin{array}{c}\text { Frekuensi } \\
\text { (f) }\end{array}$ & $\begin{array}{c}\text { Persentase } \\
(\%)\end{array}$ \\
\hline 1 & Baik & 12 & $30 \%$ \\
2 & Cukup & 13 & $3,5 \%$ \\
3 & Kurang & 15 & $37,5 \%$ \\
\hline & Jumlah & $\mathbf{4 0}$ & $\mathbf{1 0 0} \%$ \\
\hline
\end{tabular}

Sumber: Hasil penelitian bulan September 2018. 
Tabel 2 diatas menujukkan hasil analisa penelitian pengetahuan wanita pada pasangan usia subur tentang cara penularan penyakit sifilis di wilayah kerja Puskesmas Batu Aji Kota Batam tahun 2018, dari 40 responden sebanyak 12 responden (30\%), memiliki pengetahuan baik, 13 responden (32,5\%) memiliki pengetahun cukup, 15 responden $(37,5 \%)$ memiliki pengetahuan kurang.

\section{Pengetahuan tentang Cara Pencegahan Penyakit Sifilis.}

Tabel 3. Distribusi Frekuensi Tingkat Pengetahuan Wanita pada Pasangan Usia Subur terhadap Cara Pencegahan Penyakit Sifilis di Wilayah Kerja Puskesmas Batu Aji Kota Batam tahun 2018.

\begin{tabular}{|c|c|c|c|}
\hline No & Kategori & $\begin{array}{l}\text { Frekuensi } \\
\text { (f) }\end{array}$ & $\begin{array}{c}\text { Persentase } \\
(\%)\end{array}$ \\
\hline $\begin{array}{l}1 \\
2\end{array}$ & $\begin{array}{l}\text { Baik } \\
\text { Cukup }\end{array}$ & $\begin{array}{l}13 \\
15\end{array}$ & $\begin{array}{l}32,5 \\
37,5\end{array}$ \\
\hline \multirow[t]{2}{*}{3} & Kurang & 12 & 30 \\
\hline & Jumlah & 40 & 100 \\
\hline imh & $\begin{array}{c}\text { Hasil } \\
\text { Septemb }\end{array}$ & $\begin{array}{l}\text { penelitian } \\
2018\end{array}$ & bulan \\
\hline
\end{tabular}

Tabel 3 diatas menujukkan hasil analisa penelitian pengetahuan wanita pada pasangan usia subur tentang cara pencegahan penyakit sifilis di wilayah kerja Puskesmas Batu Aji Kota Batam tahun 2018, dari 40 responden sebanyak 13 responden (3,5\%), memiliki pengetahuan baik, 15 responden $(37,5 \%)$ memiliki pengetahun cukup, 12 responden $(30 \%)$ memiliki pengetahuan kurang.
4. Pengetahuan tentang Cara Pengobatan Penyakit Sifilis

Tabel 4. Distribusi Frekuensi Tingkat Pengetahuan Wanita pada Pasangan Usia Subur terhadap Cara Pengobatan Penyakit Sifilis di Wilayah Kerja Puskesmas Batu Aji Kota Batam tahun 2018

No Kategori Frekuensi Persentase

\begin{tabular}{cccc} 
& & $(\mathbf{f})$ & $(\%)$ \\
\hline 1 & Baik & 11 & $27,5 \%$ \\
2 & Cukup & 18 & $45 \%$ \\
3 & Kurang & 11 & $27,5 \%$ \\
\hline & Jumlah & $\mathbf{4 0}$ & $\mathbf{1 0 0} \%$ \\
\hline
\end{tabular}

Sumber: Hasil penelitian bulan September 2018.

Tabel 4 diatas menujukkan hasil analisa penelitian pengetahuan wanita pada pasangan usia subur tentang cara pengobatan penyakit sifilis di wilayah kerja Puskesmas Batu Aji Kota Batam tahun 2018, dari 40 responden sebanyak 11 responden (27,5\%), memiliki pengetahuan baik, mayoritas terbanyak 18 responden (45\%) memiliki pengetahun cukup, 11 responden $(27,5 \%)$, memiliki pengetahuan kurang.

Berdasarkan hasil penelitian didapatkan bahwa mayoritas wanita pada pasangan usia subur yang menjadi responden berpengetahuan cukup. Hal ini dipengaruhi oleh paparan media massa, di mana responden sering melihat informasi atau mendengar informasi dari media tersebut, baik itu media cetak maupun media elektronik, sebagai informasi yang diterima responden khususnya dalam hal kesehatan. Sehingga informasi yang 
didapat responden membantu untuk mengetahui berbagai macam informasi yang bermanfaat.

5. Pengetahuan Wanita pada Pasangan Usia Subur tentang Penyakit Sifilis

Tabel 5. Distribusi Frekuensi Tingkat Pengetahuan Wanita pada Pasangan Usia Subur terhadap Penyakit Sifilis di Wilayah Kerja Puskesmas Batu Aji Kota Batam tahun 2018.

\begin{tabular}{cccc}
\hline No & Kategori & $\begin{array}{c}\text { Frekuensi } \\
\text { (f) }\end{array}$ & $\begin{array}{c}\text { Persentase } \\
(\%)\end{array}$ \\
\hline 1 & Baik & 7 & 17,5 \\
2 & Cukup & 19 & 47,5 \\
3 & Kurang & 14 & 35 \\
\hline & Jumlah & $\mathbf{4 0}$ & $\mathbf{1 0 0}$ \\
\hline
\end{tabular}

Sumber: Hasil penelitian bulan September 2018

Tabel 5 diatas menunjukkan hasil analisa penelitian pengetahuan wanita pada pasangan usia subur tentang penyakit sifilis di puskesmas Batu Aji Kota Batam tahun 2018, dari 40 responden sebanyak 19 responden $(47,5 \%)$ mayoritas atau sebagian besar memiliki pengetahuan cukup, 7 responden $\quad(17,5 \%) \quad$ memiliki pengetahuan baik dan 14 responden (35\%) memiliki pengetahuan kurang.

\section{PEMBAHASAN}

1. Gambaran Pengetahuan Wanita pada Pasangan Usia Subur tentang Pengertian Penyakit Sifilis di Wilayah Kerja Puskesmas Batu Aji kota Batam tahun 2018.
Berdasarkan data yang diperoleh hasil penelitian pada (tabel 1) gambaran pengetahuan wanita pada pasangan usia subur tentang pengertian penyakit sifilis di wilayah kerja Puskesmas Batu Aji Kota Batam tahun 2018, dari 40 responden sebanyak 17 responden $(42,5 \%)$, mayoritas atau sebagian besar memiliki pengetahuan baik, 10 responden (25\%) memiliki pengetahun cukup, 13 responden (32,5\%) memiliki pengetahuan kurang.

Tingkat pendidikan seseorang juga diduga dapat mempengaruhi sikap dan perilaku dalam kegiatan apa saja. Tingkat pendidikan kesehatan tidak dapat segera membawa manfaat bagi masyarakat dan yang mudah dilihat dan diukur. Karena pendidikan adalah "Behavior Investment" jangka panjang dan hasilnya dapat dilihat beberapa tahun kemudian (Notoadmojo, 2012).

Berdasarkan hasil penelitian yang dilakukan peneliti bahwa mayoritas wanita pada pasangan usia subur yang menjadi responden berpengetahuan baik tentang pengertian penyakit sifilis di wilayah kerja Puskesmas Batu Aji Kota Batam tahun 2018.

2. Gambaran Pengetahuan Wanita pada Pasangan Usia Subur tentang Cara Penularan Penyakit Sifilis di Wilayah Kerja Puskesmas Batu Aji Kota Batam tahun 2018. 
Berdasarkan data yang diperoleh hasil penelitian pada (tabel 2) gambaran pengetahuan wanita pada pasangan usia subur tentang cara penularan penyakit sifilis di wilayah kerja Puskesmas Batu Aji Kota Batam tahun 2018, dari 40 responden sebanyak 12 responden (30\%), memiliki pengetahuan baik, 13 responden $\quad(32,5 \%) \quad$ memiliki pengetahuan cukup, 15 responden $(37,5 \%)$ memiliki pengetahuan kurang.

Menurut Soekidjo (2007) faktor-faktor yang mempengaruhi tingkat pengetahuan adalah pendidikan, dimana diharapkan saat orang berpendidikan tinggi, orang tersebut semakin luas pula pengetahuannya tetapi selain dari pendidikan formal informasi tersebut juga dapat diperoleh dari pendidikan Informal.

Berdasarkan hasil penelitian yang dilakukan peneliti bahwa mayoritas wanita pada pasangan usia subur yang menjadi responden berpengetahuan kurang. Kebanyakan responden salah menjawab pada pertanyaan nomor 6-10 yang dimana pertanyaan nya adalah bagaimana cara-cara penularan penyakit sifilis. Maka diambil kesimpulan bahwa responden belum memahami bagaimana penyakit sifilis itu tertular baik melalui hubungan seks bebas atau janin yang dikandung oleh ibu penderita.

3. Gambaran Pengetahuan Wanita pada Pasangan Usia Subur tentang Cara Pencegahan Penyakit Sifilis di
Wilayah Kerja Puskesmas Batu Aji Kota Batam tahun 2018.

Berdasarkan data yang diperoleh hasil penelitian pada (tabel 3) gambaran pengetahuan wanita pada pasangan usia subur tentang cara pencegahan penyakit sifilis di wilayah kerja Puskesmas Batu Aji Kota Batam tahun 2018, dari 40 responden sebanyak 13 responden (3,5\%), memiliki pengetahuan baik, 15 responden $(37,5 \%)$ memiliki pengetahun cukup, 12 responden (30\%) memiliki pengetahuan kurang.

Menurut Azwar (2012) menyatakan bahwa terdapat beberapa faktor yang mempengaruhi pembentukan sikap seseorang antara lain pengalaman pribadi, pengaruh orang lain, kebudayaan, media massa dan faktor emosional.

Berdasarkan penelitian terhadap 186 pasien IMS yang berobat ke Poliklinik Kulit dan Kelamin RSUP Dr. M. Djamil Padang maka didapatkan Pasien sifilis terbanyak berusia 26-35 tahun, memiliki jenis kelamin laki-laki, memiliki pendidikan terakhir SMA, dan memiliki pekerjaan sebagai wiraswasta (Nila, 2016).

Secara keseluruhan hasil penelitian yang dilakukan peneliti berbanding lurus dengan penelitian Nila (2016) bahwa mayoritas wanita pada pasangan usia subur yang menjadi responden berpengetahuan cukup. 
4. Gambaran Pengetahuan Wanita pada Pasangan Usia Subur tentang Cara Pengobatan Penyakit Sifilis di Wilayah Kerja Puskesmas Batu Aji Kota Batam tahun 2018.

Berdasarkan data yang diperoleh hasil penelitian pada (tabel 4) gambaran pengetahuan wanita pada pasangan usia subur tentang cara pengobatan penyakit sifilis di wilayah kerja Puskesmas Batu Aji Kota Batam tahun 2018, dari 40 responden sebanyak 11 responden (27,5\%), memiliki pengetahuan baik, mayoritas terbanyak 18 responden (45\%) memiliki pengetahun cukup, 11 responden $(27,5 \%), \quad$ memiliki pengetahuan kurang.

Menurut Pinem (2016) tingkat sosial ekonomi seseorang mempengaruhi pengetahuan, semakin tinggi tingkat sosial ekonomi akan menambah tingkat pengetahuan.

Menurut penelitian Nila (2016) terhadap 186 pasien IMS yang berobat ke Poliklinik Kulit dan Kelamin RSUP Dr. M. Djamil Padang maka didapatkan Penggunaan kondom tidak berhubungan dengan kejadian sifilis.

Secara keseluruhan penelitian yang diilakukan Nila (2016) disimpulkan berhubungan dengan hasil penelitian yang dilakukan peneliti mengenai cara pengobatan penyakit sifilis pada wanita pada pasangan usia subur, dimana tidak banyak responden atau hanya setengah dari jumlah responden yang menjawab benar mengenai cara pengobatan penyakit sifilis.

5. Gambaran Pengetahuan Wanita pada Pasangan Usia Subur tentang Penyakit Sifilis di Wilayah Kerja Puskesmas Batu Aji Kota Batam tahun 2018

Berdasarkan data yang diperoleh hasil penelitian pada (tabel 5) gambaran pengetahuan wanita pada pasangan usia subur tentang penyakit sifilis di wilayah kerja Puskesmas Batu Aji Kota Batam tahun 2018, dari 40 responden sebanyak 11 responden (27,5\%), memiliki pengetahuan baik, mayoritas terbanyak 18 responden (45\%) memiliki pengetahun cukup, 11 responden (27,5\%), memiliki pengetahuan kurang.

Tingkat pendidikan seseorang juga diduga dapat mempengaruhi sikap dan perilaku dalam kegiatan apa saja. Tingkat pendidikan kesehatan tidak dapat segera membawa manfaat bagi masyarakat dan yang mudah dilihat dan diukur. Karena pendidikan adalah "Behavior Investment" jangka panjang dan hasilnya dapat dilihat beberapa tahun kemudian (Soekidjo, 2007).

Berdasarkan penelitian terhadap 186 pasien IMS yang berobat ke Poliklinik Kulit dan Kelamin RSUP Dr. M. Djamil Padang maka didapatkan Riwayat IMS lain berhubungan dengan kejadian sifilis (Nila, 2016) 
Berdasarkan hasil penelitian yang dilakukan peneliti bahwa mayoritas wanita pada pasangan usia subur yang menjadi responden berpengetahuan cukup. Hal ini dikarenakan responden sudah cukup banyak mengetahui secara umum tentang penyakit sifilis, cara penularan, pencegahan dan pengobatannya hanya saja perlu diberikan pemahaman lebih banyak lagi agar masing-masing responden atau masyarakat menjadi lebih aktif lagi dalam mencari tahu dan menerima informasi mengenai bahayanya penyakit menular seksual (PMS) terutama penyakit sifilis.

\section{KESIMPULAN}

Dari hasil penelitian yang telah dilakukan di Puskesmas Batu Aji Kota Batam tahun 2018 dapat disimpulkan bahwa rata-rata tingkat pengetahuan wanita pada pasangan usia subur tentang penyakit sifilis menunjukkan dari 40 responden, sejumlah 19 responden $(47,5 \%)$ memiliki pengetahuan cukup, 7 responden (17,5\%) memiliki pengetahuan baik dan 14 responden (35\%) memiliki pengetahuan kurang. Berdasarkan hasil penelitian dapat disimpulkan tingkat pengetahuan wanita pada pasangan usia subur tentang penyakit sifilis di Puskesmas Batu Aji Kota Batam tahun 2018, memiliki pengetahuan cukup tentang penyakit sifilis.

\section{DAFTAR PUSTAKA}

Azwar, Saifuddin. 2012. Sikap Manusia Teori dan Pengukurannya. Yogyakarta:

Pustaka Belajar.
Dinas Kesehatan Kota Batam Tahun 2015 tentang daftar Pasangan Usia Subur di Kota Batam dan Daftar Riwayat Penyakit Sifilis di tahun 2015 di Kota Batam.

Dinas Kesehatan Kota Padang Tahun 2014 tentang Kejadian Sifilis tahun 2013 di Kota Padang.

Djuanda A. 2010. IImu penyakit kulit dan kelamin Edisi keenam. Jakarta: Badan Penerbit FKUI.

Machfoedz, Mahmud. 2010. Komunikasi Pemasaran Modern, Yogyakarta: Cakra IImu.

Nila, Pebryanti. 2016. Hubungan Perilaku Seksual Beresiko dengan Kejadian Sifilis di Poliklinik Kulit dan Kelamin RSUP. DR. M. Jamil Padang Periode 2011-2015. Tesis: Universitas Andalas. Padang.

Notoadmojo. 2012. Metodologi Penelitian Kesehatan. Jakarta: Rineka Cipta.

Pan American Health Organization. 2018. Syphilis. https://www.paho.org/hq/index.-php?option=com_content\&view=article\&id=1486 9 :stisyphilis\&ltemid=3670\&lang=en. Diakses pada 02 September 2018.

Pinem, Mbina. 2016. Pengaruh Pendidikan dan Status Sosial Ekonomi Kepala Keluarga bagi Kesehatan. Jurnal IImu Pemerintahan dan Sosial Politik. 4 (1): 97-106.

Profil Kesehatan Provinsi Lampung 2013, Profil Kesehatan Provinsi Lampung Tahun 2012. Lampung: Dinas Kesehatan Provinsi Lampung. Diakses pada 02 September 2018.

Profil Kesehatan Provinsi Jateng 2015. Profil Kesehatan Provinsi Jateng Tahun 2015. Jateng: Dinas Kesehatan Provinsi Jateng. Diakses pada 02 September 2018.

Sarwono. 2009. IImu Kandungan edisi kedua cetakan ketujuh. Jakarta: Yayasan Bina Pustaka. 
Saryono. 2013. Metodologi Penelitian

Kualitatif dan Kuantitatif dalam Bidang

kesehatan cetakan pertama.

Yogyakarta: NuhaMedika.

Soekidjo, Notoatmodjo. 2013. IImu Perilaku Kesehatan Mayarakat. Jakarta:

Rineka Cipta. 